DOI: https://doi.org/10.47405/mjssh.v5i2.362

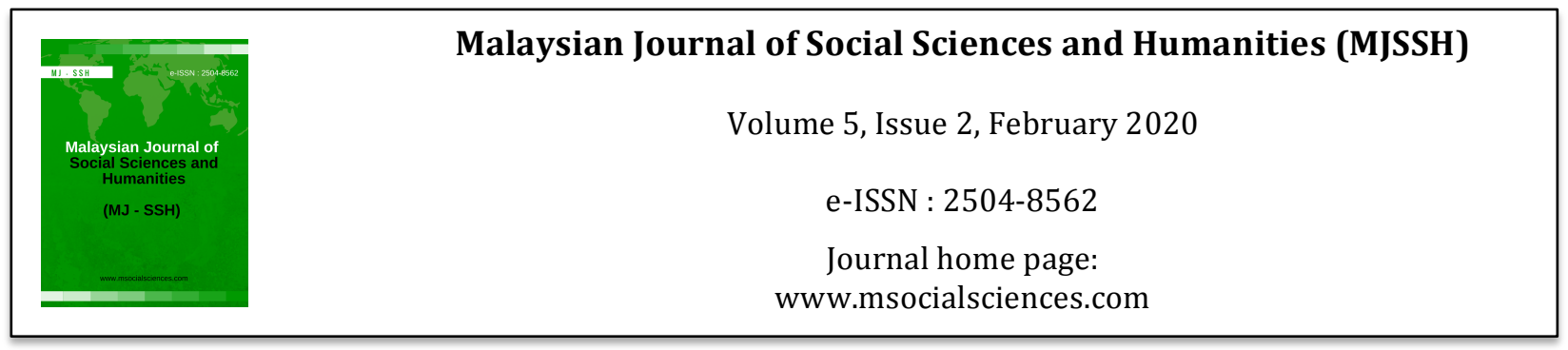

\title{
Kepentingan Industri Pertahanan Malaysia Kepada Keselamatan Negara
}

\author{
Mohamed Fajil Abd. Batau', Nazariah Osman', Mohamad Faisol Keling1 \\ ${ }^{1}$ College of Law, Government and International Studies, Universiti Utara Malaysia (UUM) \\ Correspondence: Mohamed Fajil Abd. Batau (fajil_batau@uitm.edu.my)
}

\begin{abstract}
Abstrak
Selepas kemerdekaan 1957 sehingga sekarang, keselamatan negara merupakan perkara utama yang diberi perhatian oleh kerajaan dalam menangani pelbagai bentuk ancaman kepada keselamatan negara. Jesteru itu satu Dasar Keselamatan Negara (DKN) dan Dasar pertahanan Negara (DPN) telah digubal dalam mempertahankan kedaulatan dan keamanan Negara Malaysia. Dasar Pertahanan Negara (DPN) ini juga telah menggariskan salah satu komponen strategi pertahanan iaitu Industri Pertahanan (IP) yang perlu dibangunkan untuk keperluan pembangunan keupayaan aset pertahanan ketenteraan Angkatan Tentera Malaysia (ATM). Oleh itu, Pembangunan Industri Pertahanan Malaysia akan memberikan impak kepada keselamatan negara dan artikel ini membincangkan kepentingan (IP) kepada Keselamatan Negara secara amnya. Pembangunan (IP) juga akan memberi satu keupayaan pertahanan yang kukuh dalam kesiapsiagaan menangani ancaman daripada luar dan dalam negara.
\end{abstract}

Kata kunci: keselamatan negara, industri pertahanan, ancaman keselamatan

\section{Importance of Malaysian Defense Industry Towards National Security}

\begin{abstract}
After the independence of 1957 until now, national security has been the main concern of the government in dealing with all types of threats. Therefore, the National Security Policy (NSP) and the National Defense Policy (NDP) have been formulated to defend the country's sovereignty and security. The National Defense Policy (NDP) has also outlined one of the defense strategy components, namely the Defense Industry that needs to be developed for the purpose of developing the Malaysian Arm Force military's asset capabilities. Therefore, the Defense Industry Development in Malaysia will have an impact on National Security and this article discussed the importance defense industry to National Security in general. Development of Defense Industry will provide a strong defense capability in preparing for external and domestic threats.
\end{abstract}

Keywords: national security, defense industry, security threats

\section{Sejarah perkembangan Dasar Pertahanan Malaysia (DPN)}

Dasar Pertahanan Negara (DPN) merupakan satu tindakan ataupun polisi kerjaan yang digubal dalam mempertahankan, melindungi kedaulatan dan kepentingan negara. Dasar Pertahanan Negara DPN juga 
merupakan salah satu dokumen rasmi yang digubal dalam proses perundangan sebelum menjadi satu dasar pertahanan yang komprehensif. (DPN) juga boleh diistilahkan sebagai satu panduan dan objektif kerajaan bagi mempertahankan kedaulatan dan menjaga kepentingan nasional daripada ancaman dalam dan luar negara. (DPN) ini juga digubal dengan mengambilkira pelbagai aspek yang merangkumi faktor geografi, ancaman dalaman dan luaran yang menjadi penyumbang maklumat dalam mempengaruhi perlaksanaan (DPN) itu sendiri. Ianya juga satu tindakan dan keputusan kerajaan untuk menjaga kepentingan nasional daripada pelbagai bentuk ancaman yang tidak menentu serta keupayaan kerajaan dalam megambil tindakan sewajarnya mengikut bentuk ancaman yang dihdapi. Selain itu juga, (DPN) ini menjadi satu rujukan, hala tuju strategi pertahanan negara dan pelaksanaannya melalui Angkatan Tentera Malaysia (ATM) itu sendiri dan agensi yang berkaitan dengannya. ${ }^{1}$

\section{Pembangunan Industri Pertahanan Malaysia}

Pembangunan Industri Pertahanan Malaysia telah bermula sejurus selepas kemerdekaan negara iaitu pada tahun 1960an dan pada ketika itu industri pertahanan negara memiliki keupayaan yang minimum sahaja iaitu keupayaan dalam penyelenggaraan dan membaik pulih logistik ATM (Angkatan Tentera Malaysia). Objektif utama pada ketika itu ialah membantu dalam menyokong logistik Ketenteraan Malaysia bagi menjadikan ATM berdikari sendiri dalam industri ini. Selain itu, fokus industri pertahanan negara pada ketika itu hanya memenuhi keperluan unit - unit dibawah naungan ATM, usaha pembangunan ini dapat dilihat apabila Syarikat SME Ordnance Sdn. Bhd atau dikenali dengan Syarikat Malaysia Explosive Sdn. Bhd. iaitu salah satu syarikat tempatan yang menyediakan keperluan pertahanan pada ketika itu dengan pembuatan senjata dan bahan letupan. Selain itu, sebuah sektor Syarikat dalam Industri Aeroangkasa Malaysia iaitu AIROD Sdn. Bhd (Airod Inspection, Repair \& Overhaul Depot) telah ditubuhkan pada tahun (1976) dalam menyediakan keperluan logistik Angkatan Tentera Udara Malaysia. Ini menunjukkan bahawa usaha - usaha awal daripada Kerajaan Malaysia dalam membangunkan industri pertahanan negara secara berdikari (Self-Reliance). Selain itu, beberapa agensi, jabatan kerajaan dan syarikat tempatan telah ditubuhkan dalam usaha membangunkan industri pertahanan negara seperti Institut Penyelidikan Sains \& Teknologi Pertahanan (STRIDE) dan DRBHICOM Defence Technologies Sdn Bhd (DEFTECH). Usaha ini memperlihatkan komitmen kerajaan dalam menjaga keselamatan negara dengan memastikan ATM dapat mempersiapkan aset-aset pertahanan yang seiring dengan peredaran zaman.

Pada tahun (1999), dalam usaha untuk membangunkan dan memantapkan industri pertahanan tempatan satu Majlis Industri Pertahanan Malaysia (MIPM) telah ditubuhkan dan sekarang dikenali dengan Majlis Industri Bagi Pertahanan, Penguatkuasaan dan Keselamatan (MIDES) bagi mengawal selia perkembangan industri yang strategik ini. Beberapa objektif digubal dalam usaha membangunkan industi pertahanan tempatan yang selari dengan keperluan ATM. Ini menunjukkan perkembangan industri pertahanan negara terus diberi perhatian oleh kerajaan dalam memastikan keberlangsungan permodenan dan pembangunan kepada aset dan sistem pertahanan negara. Secara dasarnya, industri pertahanan membentuk sebahagian kemampuan pertahanan dalam menjaga keselamatan negara. Sesebuah negara yang memiliki industri pertahanan yang maju dapat menyumbang bukan sahaja kepada keselamatan negara itu sendiri malah ianya mampu membangunkan sosio- ekonomi sesebuah negara serta ianya juga mampu menyediakan struktur dan perkhidmatan sokongan yang sangat mempengaruhi kesediaan operasi bagi sesebuah angkatan tentera.

Secara rasionalnya, salah satu faktor utama industri pertahanan sesebuah negara dibangunkan kerana keperluan kepada keselamatan negara. Industri pertahanan Malaysia agak berkembang dengan kadar yang minima walaupun ianya telah diwujudkan selepas kemerdekaan melalui pergantungan kepada negara luar dari aspek pemerolehan dan pembuatan aset- aset ketenteraan. Walau bagaimanapun, kerajaan tetap komited dalam membina industri ini dan ianya merupakan salah satu usaha untuk mendapat impak yang positif terutamanya dalam sektor ekonomi mahupun keselamatan negara itu sendiri. Di dalam konteks sistem hubungan negara, keperluan industri pertahanan merupakan salah satu

\footnotetext{
${ }^{1}$ Chandra Jeshrun (1980). Malaysia Defence Policy: A Study In Parliament Attitudes: 1963-1974. Kuala Lumpur: Universiti Malaya. hlm11-17.
} 
usaha strategik dalam menjaga ancaman daripada negara lain. Negara - negara maju seperti Russia dan Amerika Syarikat merupakan pengeluar yang maju dalam industri ini sekaligus memberikan persepsi ancaman keselamatan yang tinggi kepada negara - negara lain. Keupayaan aset pertahanan yang cekap membolehkan sistem pertahanan akan lebih mantap dan sekaligus dapat menjaga keselamatan negara secara efisien.

\section{Keperluan Industri Pertahanan kepada Keselamatan Negara}

\section{Membina Keupayaan Pertahanan Secara Berdikari}

Menurut (Neuman,1988), Bagi kebanyakan negara - negara membangun, faktor utama untuk membangunkan perindustrian pertahanan adalah satu keperluan untuk mengurangkan kebergantungan kepada pembekal asing atau negara lain dalam membina keupayaan pertahanan mereka sendiri. Pembangunan (IP) juga akan meningkatkan keselamatan sesebuah negara dengan tidak bergantung terus sepenuhnya terutamanya apabila berlakunya krisis dan konflik. Bagi sesebuah negara pengguna dan pengimport kepada aset pertahanan, ianya akan menyebabkan satu ancaman kerana sejarah telah menunjukkan bahawa negara - negara pengimport sangat terdedah kepada embargo dan sekatan sekaligus mengundang masalah dalam kesiagaan sistem pertahanan negara.

Ancaman keselamatan terhadap negara adalah sebagai faktor penting bagi negara untuk membangunkan industri pertahanannya sendiri. Beberapa sarjana dan penganalisis pertahanan berpendapat tiada satu negara pun mempunyai kebebasan yang mutlak kerana di dalam sistem hubungan antarabangsa kebiasaannya wujud persepsi ancaman dan krisis yang tidak menentu. Selain itu juga, salah satu usaha dalam mewujudkan keselamatan negara adalah dengan meningkatkan aplikasi sains dan teknologi dalam pengeluaran, pemerolehan dan memodenkan aset - aset dan peralatan sokongan ketenteraan. Oleh itu, persepsi dan tahap ancaman dan persekitaran keselamatan yang tinggi kepada sesebuah negara akan mampu meningkatkan pembangunan teknologi ketenteraan. Ini menunjukkan bahawa faktor keselamatan amat penting dengan adanya dasar industri pertahanan negara.

Malaysia telah melalui evolusi yang mencabar dalam memelihara kedaulatan, keselamatan negara dan ketenteraman awam. Landskap keselamatan kini semakin kompleks melibatkan ancaman-ancaman dari pelaku negara (state actor) dan pelaku bukan negara (non-state actor) yang berpotensi memberikan impak besar ke atas keselamatan serta kedaulatan negara. Pengalaman lalu yang pernah dihadapi negara dari segi keselamatan termasuklah kolonialisme kuasa asing, keganasan komunis, Konfrontasi Indonesia, pemisahan wilayah, konflik perkauman 13 Mei 1969, ekstremisme (kaum, ideologi, agama dan politik), krisis ekonomi, bencana alam dan pencerobohan wilayah. Usaha memastikan keselamatan negara dan kelangsungan Malaysia sebagai sebuah negara berdaulat kerajaan perlu mengambilkira aspek ancaman dalam negara dan suasana geopolitik di peringkat serantau dan antarabangsa.

\section{Keutuhan Dalam Menjaga Keselamatan Negara}

Keselamatan negara sentiasa berkait dengan ancaman terhadap satu negara. Menurut Mazhar Palil (1996) kemajuan Teknologi dalam aset dan persenjataan ketenteraan dengan memiliki industri pertahanan sendiri adalah fokus yang utama kepada sesebuah negara. Selain itu juga, dengan membangunkan industri pertahanan, ianya adalah usaha yang strategik dalam menyumbang kepada pencegahan, pertahanan berdikari dan keutuhan dalam menjaga keselamatan negara. ${ }^{2}$ Selain daripada faktor sekatan daripada negara pengeluar, pembangunan (IP) ini juga adalah demi menjaga keselamatan negara secara menyeluruh, keperluan (IP) ini juga adalah mencegah ancaman pengganas yang semakin meningkat, mengawal lanun dan pemancing haram, pendatang tanpa izin, aktiviti

\footnotetext{
${ }^{2}$ Mazhar Palil (1996), Military Technology: Its Impact On Malaysian Security.
} 
penyeludupan dadah, dan kegiatan jenayah rentas sempadan seperti penyeludupan manusia dan dadah di sesebuah negara yang berdaulat.

Oleh itu, keperluan kepada aset pertahanan dan keselamatan yang maju dan berteknologi tinggi diperlukan. Ini dapat dilihat dalam peningkatan permintaan untuk pengawasan maritim, darat dan juga udara. Keperluan kepada sistem atau aset pertahanan utama terdiri daripada tujuh kategori senjata konvensional iaitu: Kereta Kebal, Kenderaan Kombat Berperisai, Sistem Artileri berskala Besar, Pesawat Tempur, Helikopter Serangan, Kapal Perang dan Peluru Berpandu. Aset - aset pertahanan ini amat penting dan signifikan dalam menjaga keselamatan nasional terutamanya di sempadan sempadan negara dan kawasan pengawasan yang sangat luas dan mencabar. Peralatan keselamatan seperti kamera keselamatan di lapangan terbang, sistem biometrik dan sistem pengawasan video dan lain - lain aset juga diperlukan untuk mengawal dan mengurangkan ancaman keselamatan negara terutamanya di pintu masuk negara. Keperluan kepada pembangunan (IP) juga sangat penting bagi menjaga keselamatan negara daripada pelbagai pihak kerana dalam sistem hubungan antarabangsa pelbagai ancaman tidak dapat dijangka dan tidak menentu.

Bagi Negara Malaysia tahap persekitaran keselamatan boleh dikatakan stabil diperingkat negara mahupun rantau Asia, walau bagaimanapun, sistem pertahanan Malaysia dinaungi oleh (ATM) itu sendiri perlu bersedia untuk menghadapi ancaman - ancaman baru seperti bencana alam, wabak penyakit, jenayah rentas, kegiatan pengganas dan pemisah serta . Dengan adanya Industri pertahanan yang maju melalui usaha pemerolehan dan pembuatan aset persenjataan yang moden membolehkan ancaman ini dapat dikurangkan. Bagi Malaysia untuk mencapai matlamat keselamatan negara, kerajaan telah memastikan pembangunan industri pertahanan negara berkembang dengan beberapa sektor diberi perhatian iaitu sektor aeroangkasa, sektor maritim, automotif, persenjataan, teknologi maklumat dan komunikasi, industri peralatan gunasama, pameran pertahanan antarabangsa dan penyelidikan. ${ }^{3}$ Ini menunjukkan bahawa kerajaan Malaysia komited dalam membangunkan IP negara yang berstrategik bagi menjaga keselamatan negara. Selain itu juga pemerolehan aset - aset pertahanan seperti Kapal Selam kelas perdana menteri (KD Tun Abdul Razak \& KD Tun Abdul Rahman) memainkan peranan dalam pengawasan dan rondaan di Laut china Selatan, kapal perang TLDM (Tentera Laut Diraja Malaysia) dikerah dalam membuat pengepungan di kawasan timur sabah bagi menghalang kemasukan ancaman daripada pengganas.

Selain itu juga TLDM juga mengoperasikan kira-kira 6 buah helikopter Anti-Kapal Selam (AntiSubmarine Warfare), helikopter maritim yang berkemampuan iaitu AW-159 Wildcat dan SH-60 Seahawk. Manakala Tentera Darat Malaysia (TDM) mempunyai kenderaaan berperisai iaitu ACV-300 Adnan atau beroda AV8 Gempita dan infantri para dan mekanize di mana mempunyai kemampuan tempur yang agak baik. Bagi TUDM aset pertahanan seperti Su-30MKM, F/A-18D Hornet, Hawk 108/208, C-130h dan S-16A-4 Nuri digunakan dalam sistem pertahanan di udara. Selain itu juga beberapa aset pertahanan strategik dan bukan strategik yang lain boleh memberikan kelebihan kepada ATM dalam menjaga sempadan dan kepentingan negara daripada ancaman dalaman mahupun luaran.

Keselamatan negara ianya ditafsirkan sebagai mempertahankan nilai-nilai kemerdekaan, kedaulatan, menentukan keselamatan rakyat, agar berada ditahap yang selesa dalam erti kata lain hidup dalam suasana yang harmoni dan aman damai. ${ }^{4}$ Keselamatan negara merupakan satu konsep yang wujud selepas perang dunia pertama dan kedua, ianya melibatkan ketenteraan pada awalnya dan konsep keselamatan negara itu meluas. Keselamatan negara juga bermaksud menjaga pertahanan sempadan negara daripada ancaman ketenteraan dan musuh supaya ia wujud sebagai sebuah negara yang merdeka dan berdaulat. Monica Gariup, (2017), pula mendefinisikan keselamatan sebagai dasar kerajaan untuk mewujudkan keadaan aman yang melindungi kepentingan utama negara daripada ancaman musuh. ${ }^{5}$

\footnotetext{
${ }^{3}$ Hamzah Hi Dollah, Ancarnan Alaf Baru. Perajurit Penjana Pemikiran Pertahanan, Mac 2009 , p. 62 .

4 Satish Chandra \& Rahul Bhonsle (2015) National Security: Concept, Measurement and Management, Strategic Analysis, 39:4, 337-359,

${ }^{5}$ Monica Gariup, (2017), European Security Culture: Language, Theory, Policy, Taylor \& Francis.
} 
Konsep keselamatan negara Malaysia telahpun dibincangkan dan dinyatakan dalam Dasar Pertahanan Negara yang mengambil kira enam prinsip utama ${ }^{6}$, iaitu, Berdikari (self-reliance), Pertahanan menyeluruh (HANRUH), Komitmen Terhadap Peraturan Pertahanan Lima Negara (FPDA). Sokongan kepada usaha PBB ke arah keamanan sejagat, Langkah-langkah terhadap keganasan dan Diplomasi pertahanan. ${ }^{7}$ Selain itu juga salah satu komponen dalam DPN ataupun strategi pertahanan adalah dengan membangunkan industri pertahanan yang kukuh.

Industri pertahanan negara dapat membantu Malaysia terus berusaha ke arah meningkat dan membangunkan keupayaan ATM. Perdana Menteri Malaysia Tun Mahathir Mohamad, di Pameran Aeroangkasa dan Maritim Antarabangsa Langkawi 2019 (LIMA'19):

\begin{abstract}
"Pelaburan dalam sektor keselamatan akan melibatkan melengkapkan Angkatan Tentera dengan persenjataan dan teknologi terkini. Kita merancang untuk menjadikan Malaysia sebagai negara aeroangkasa terkemuka di Asia Tenggara dan bahagian penting dalam pasaran global sebagaimana yang nyatakan dalam Rangka Tindakan Industri Aeroangksa Malaysia 2030”. (Tun Mahathir Mohamad,2019) ${ }^{8}$
\end{abstract}

Beliau juga menegaskan keperluan industri pertahanan perlu dinaiktaraf dan maju supaya dapat menangani ancaman keselamatan yang moden. Ini juga dapat dilihat usaha kerajaaan dalam menjaga keselamatan dengan memperuntukkan RM5.9 bilion bagi sektor keselamatan yang merangkumi pertahanan dan penguatkuasaan. Ini menunjukkan pembangunan industri pertahanan negara telah menjadi salah satu dasar yang akan memantapkan lagi pertahanan dan keselamatan negara dengan pembangunan dan pembelian aset pertahanan yang berteknologi tinggi. Pembangunan industri pertahanan negara penting dalam menangani segala ancaman dari luar dan dalam negara melalui permodenan peralatan pertahanan dan juga keupayaan ketenteraan, Ini menunjukkan perlaksanaan industri pertahanan tempatan telah mula bersiap sedia untuk terus komited dalam membangunkan aset - aset pertahanan dalam meningkatkan tahap pertahanan negara dan pada masa yang sama menjadi angkatan yang disegani dan kredibel di rantau Asia ini. ${ }^{9}$

\title{
Kesimpulan
}

DPN merupakan asas kepada strategi pertahanan negara dan menekankan beberapa komponen dalam membentuk dan merancang pertahanan negara daripada pebagai bentuk ancaman. Industri pertahanan adalah salah satu komponen dalam DPN yang dibangunkan mengikut acuan Malaysia yang membolehkan negara dapat menjaga keselamatan negara dengan memenuhi keperluan aset dan sistem pertahanan ATM itu sendiri. Selain itu juga, Industri pertahanan yang maju dapat menjaga dan mengurangkan ancaman kepada keselamatan negara, walaupun pada masa kini tidak ada tanda - tanda akan berlakunya peperangan terutamanya di rantau Asia namun ancaman - ancaman keselamatan moden yang baru sedikit sebanyak akan memberikan impak negatif kepada kedaulatan dan keselamatan Negara Malaysia. Pertubuhan - pertubuhan kecil dalam negara yang berkonflik yang berorientasikan perjuangan menentang penjajahan kuasa besar atau pemberontakan menentang kerajaan yang tidak sehaluan dengan mereka juga salah satu ancaman yang boleh mengugat keselamatan Negara. Ancaman - ancaman semasa yang tidak menentu dan sukar diramal memerlukan keupayaan - keupayaan aset pertahanan yang hanya boleh dimajukan melalui pembangunan industri pertahanan. Secara kesimpulannya, keperluan sistem pertahanan dalam keadaan kesiapsiagaan,

\footnotetext{
${ }^{6}$ National Defence Policy. Halaman 15-17.

${ }^{7}$ Mohamad Faisol, Keling (2016) Op.Cit.

${ }^{8}$ Lima Jadikan Malaysia Seiring Dengan Perkembangan Industri Pertahanan - Pm Mahathir Mac 26, 2019. Bernama.

${ }^{9}$ P.K Sengupta Dan Muhammad Fuad Mat Nor (2002). Cabaran Atm Dan Pemodenan Td. Perajurit. September. Hlm 2-7
} 
DOI: https://doi.org/10.47405/mjssh.v5i2.362

profesional dan mernpunyai kelengkapan aset pertahanan yang cukup serta tahap kesediaan yang baik akan memberi impak positif kawalan keselamatan Negara Malaysia.

\section{Rujukan}

Chandra Jeshrun (1980). Malaysia Defence Policy: A Study In Parliament Attitudes: 1963-1974. Kuala Lumpur: Universiti Malaya. hlm11-17.

Hamzah Hi Dollah, Ancarnan Alaf Baru. Perajurit Penjana Pemikiran Pertahanan, Mac 2009, p.62.

Lima Jadikan Malaysia Seiring Dengan Perkembangan Industri Pertahanan - Pm Mahathir Mac 26, 2019. Bernama.

Mohamad Faisol, Keling (2016) Dasar pertahanan negara Malaysia: Analisis ke atas prinsip pertahanan self-reliance. $\mathrm{PhD}$. thesis, Universiti Utara Malaysia.

Mazhar Palil (1996), Military Technology: Its Impact On Malaysian Security.

National Defence Policy. Halaman 15-17. Diakses melalui https://www.pmo.gov.my/wpcontent/uploads/2019/07/National-Defence-Policy.pdf

Stephanie G. Newman 1988. Arms, aid and the superpowers. Foreign affairs, 66 (5), 1044-1066.

Stein G. S (2013), Threat Perceptions in International Relations, the Oxford Handbook of Political Psychology 2n. edition.

Satish Chandra \& Rahul Bhonsle (2015) National Security: Concept, Measurement and Management, Strategic Analysis, 39:4, 337-359.

P.K Sengupta dan Muhammad Fuad Mat Nor (2002). Cabaran ATM Dan Pemodenan TD. Perajurit. September. hlm 2-7 